\section{A journal of histochemistry as a forum for non-histochemical scientific societies}

\author{
Carlo Pellicciari, ${ }^{1}$ Marco Biggiogera, ${ }^{1}$ \\ Manuela Malatesta ${ }^{2}$ \\ ${ }^{1}$ Department of Biology and \\ Biotechnology, University of Pavia \\ ${ }^{2}$ Department of Neurosciences, \\ Biomedicine and Movement Sciences, \\ University of Verona, Italy
}

\begin{abstract}
Histochemical techniques are widely applied in biomedical research and, during the last twenty years, they were among the methods used in more than 590,000 scientific articles in indexed journals. However, a very small percentage of these papers were published in strictly histochemical journals. A possible strategy to widen the audience of the histochemical journals making them attractive to non-histochemist authors might be to publish and make open-access available the proceedings of the meetings and conferences of valued scientific societies whose fellows use microscopy and histochemistry in their experimental activity. In the last years' experience of the European Journal of Histochemistry, this approach was effective to increase the number of published articles on stem cells and development, connective tissue and nerve cell biology.
\end{abstract}

\section{Introduction}

Histochemical methods and techniques at light and electron microscopy have wide application in a great variety of subjects in biology and medicine, ${ }^{1,2}$ from basic cell biology in animals and plants, ${ }^{3}$ to zoology and botany, developmental biology, cytogenetics, functional and morbid anatomy, pathology, ${ }^{4}$ tumor cell biology, ${ }^{5}$ and so forth. Thus it is not surprising that histochemistry in all its aspects (basic histochemistry, immunohistochemistry, enzymeand lectin histochemistry, in situ hybridization) have been used in more than 590,000 scientific articles published in indexed biomedical journals, during the last twenty years (source: https://pubmed.ncbi.nlm. nih.gov/).

The great majority (more than $98 \%$ ) of these articles have been published in nonhistochemical journals: this confirms that histochemistry is a powerful (and often irreplaceable) tool for scientists with very different research interests and expertise, ${ }^{6}$ thanks to the ability histochemical techniques have to locate single molecular components in situ, i.e. in the spatial location where their structural and functional roles are exerted in cells, tissues and organs..$^{7-9}$ On the other hand, this may also suggest that histochemical journals have progressively become less appealing for authors who may mistakenly see them as too technically-oriented. ${ }^{4}$

Raymond Coleman properly wrote ${ }^{5}$ "the contributions of histochemistry to cell and molecular biology are not always given the credit it deserves" being histochemistry often perceived as a methodological archaic discipline. In fact, the histochemical journals since their foundation (in the fifties of the last century, for the oldest ones) have surely been devoted to the development of original methods and techniques for detecting and dynamically track specific molecules, and to design novel applications on living organisms; however, as one may read in their aims and scope (see, e.g. ${ }^{11-15}$ ), the interest is explicitly expressed also for molecular and functional cytology and histology as well as for the mechanistic study of embryonic development, cell differentiation, and diseases. As such, the histochemical journals should naturally be a forum not only for the strict histochemical community, but also for a large and diverse range of scientists in biology and medicine.

\section{A possible strategy to widen the audience of a histochemical journal}

All over the world, most of the histochemical journals were founded by members of national Societies of histochemistry, or serve as their official organs: this is the case, e.g., for Histochemistry (now Histochemistry and Cell Biology), ${ }^{11}$ The Journal of Histochemistry and Cytochemistry, ${ }^{12}$ Acta Histochemica et Cytochemical, ${ }^{13}$ Folia Histochemica et Cytobiologica, ${ }^{14}$ and the Rivista di Istochimica Normale e Patologica (now European Journal of Histochemistry ${ }^{15}$ ). Thus, at least in principle, the Societies' fellows should primarily consider these journals for submitting their manuscripts; the journals, for their part, should promote diffusion of the associates' scientific results in view of the general progress of the discipline.

One of the ways to achieve this goal is to publish the proceedings of the Society meetings and conferences thus making them available to the scientific community: the European Journal of Histochemistry, for instance, has regularly published the congress proceedings of the Italian Society of Histochemistry from $1958^{16}$ (Figure 1) to present. ${ }^{17}$ These journal supplementary issues provide a detailed record on how his-
Correspondence: Carlo Pellicciari, Dipartimento di Biologia e Biotecnologie "Lazzaro Spallanzani"

Università degli Studi di Pavia, via A. Ferrata 9, 27100 Pavia, Italy.

E-mail: carlo.pellicciari@unipv.it

Key words: Congress proceedings; stem cells; connective tissue; nerve cells.

Received for publication: 22 December 2019. Accepted for publication: 23 December 2019

This work is licensed under a Creative Commons Attribution-NonCommercial 4.0 International License (CC BY-NC 4.0).

CCopyright: the Author(s), 2019

Licensee PAGEPress, Italy

European Journal of Histochemistry 2019; 63:3106 doi:10.4081/ejh.2019.3106

tochemistry developed in Italy over the last sixty years, but were -at the time of their publication (and today as well)- a snapshot of the current state and interests of the histochemical research.

Since 2000, the policy of the European Journal of Histochemistry is to host the proceedings of symposia or conferences organized, under the auspices of the Italian Society of Histochemistry, by national research institutions or scientific societies. Among them, the Italian Embryological Group (now GEI-Italian Society of Development and Cell Biology, in 201618), the Italian Society for the Study of the Connective Tissue $(2005,2009-18)$, and the Italian Society of Neuromorphology (2013 and 2014). In addition, the abstracts of several scientific meetings were also published: the "Pavia symposium on embryos and stem cells", ${ }^{18}$ the XXII Annual Meeting of the Italian Group for Ultrastructural Pathology, ${ }^{19}$ and the Conferences "Correlative Microscopy in Life and Materials Sciences"20 and "Therapeutic nanoproducts: from biology to innovative technology". ${ }^{21}$ In recent years, the national congresses of the Italian Society of Histochemistry have jointly been organized with the two other scientific Societies whose fellows have microscopy and histochemistry among the technologies and methods in their investigations: ${ }^{17,22,23}$ the GEI-Italian Society of Development and Cell Biology), in 2015 and 2019, and the Italian Society of Anatomy and Histology, in 2017.

These joint conferences as well as the other scientific events were the occasion for mutual exchange of information and for establishing research collaborations among histochemists and scientists from other disciplines; but they were they also important 
for the journal were the proceedings were open-access published, as the journal website was visited by a number of new nonhistochemist readers.

This was surely helpful to widen the journal's audience and a proof may be found browsing the journal regular issues in the period 2001-19, with attention to the articles on stem cells and development, the connective tissue, and nerve cells. The aggregate percentage of the paper published on these subjects has progressively increased from about $20 \%$ in 2001-10 to near 40\% in 2017-19 (Figure 2).

It is worth noting that not only the number of papers on these subjects increased especially in recent years, but also -even more importantly- novel applications for the histochemical approach were proposed. As for development and stem cells, besides the descriptive papers of protein expression during embryogenesis under natural or experimental conditions, ${ }^{24-33}$ articles were published on the role of stem cells in the origin and progress of diseases ${ }^{34,35}$ or on their application in regenerative medicine..$^{36-38}$ On this last subject, the stem cells derived from the connective tissue (namely from the adipose tissue) proved to be especially promising. ${ }^{39-41}$ Chondrogenesis and osteogenesis were investigated not only during normal embryological development but also in the attempt to elucidate the origin of joint diseases, such as osteoarthritis. ${ }^{42-46}$ Immunohistochemistry was essential to demonstrate the embryological origin of hemopoietic cells in non-mammalian vertebrates, ${ }^{47,48}$ and to describe the interaction of non-myelinating Schwann cells with immune cells in the mouse lymphoid organs. ${ }^{49-51}$ The basic cell mechanisms of apoptosis and autophagy proved to play key roles during the pre- and postnatal development of the cochlea in rodents ${ }^{27,52,53}$ as well as during senescence in culture of sheep neurons and astrocytes. ${ }^{54}$ The effect of cadmium was found to alter glial architecture in the lizard brain, ${ }^{55}$ and to induce neurodegeneration in zebrafish embryos and adults, ${ }^{56}$ while the effects of drug administration on the brain following trauma were studied in rat. ${ }^{57} \mathrm{~A}$ modified method of combined fixation in formalin and formic acid was described to obtain high quality immunolabeling of long-stored paraffinembedded autoptic adult brains, ${ }^{58}$ and original staining protocols were proposed to visualize on thick brain sections the cortical microinfarcts that frequently remain undetected by standard neuroimaging protocols. ${ }^{59}$

In spite of the present trend towards Big Data collection, there will always be the need for observation at the level of single tissue, single cell, single molecule.

\section{Concluding remarks}

The Editors of Histochemistry and Cell Biology recently reviewed the origin and evolution of their journal, recalling the $60^{\text {th }}$ anniversary of its founding, in 1958:60 while commenting the change of the journal's name from the original, Histochemistry to the pres- ent one, they wrote "though the name may have changed to reflect the growth and maturation of both scientific publishing practices, as well as the science itself, the underlying objectives to publish high-quality manuscripts illustrating technical innovations in histochemistry and their application in original research in cell and molecular sciences have remained steadfast guiding principles".

\section{VOLUME IV \\ (Riv. Istoch. norm. pat.) \\ O TTOBRE \\ FASCICOLO $\mathrm{V}^{\mathrm{N}}$ \\ RIVISTA DI ISTOCHIMICA}

\section{NORMALE E PATOLOGICA}

ORGANO UFFICIALE DELLA SOCIETA' ITALIANA DI ISTOCHIMICA

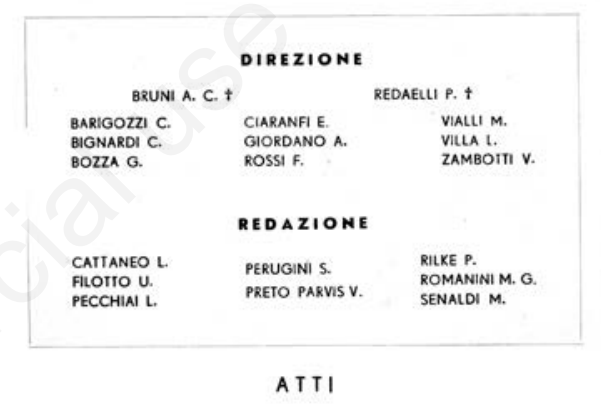

DEL I CONGRESSO NAZIONALE DELLA SOCIETA ITALIANA DIISTOCHIMICA

MESSINA 15-17 OTTOBRE 1958

Industrio Poligrofico Lombarda - V. Vialo Teodorico N. S. Millono

Figure 1. Front page of the fifth issue of Volume IV, 1958 of the journal Rivista di Istochimica Normale e Patologica where the proceedings of the $1^{\text {st }}$ National Congress of the Italian Society of Histochemistry were published.

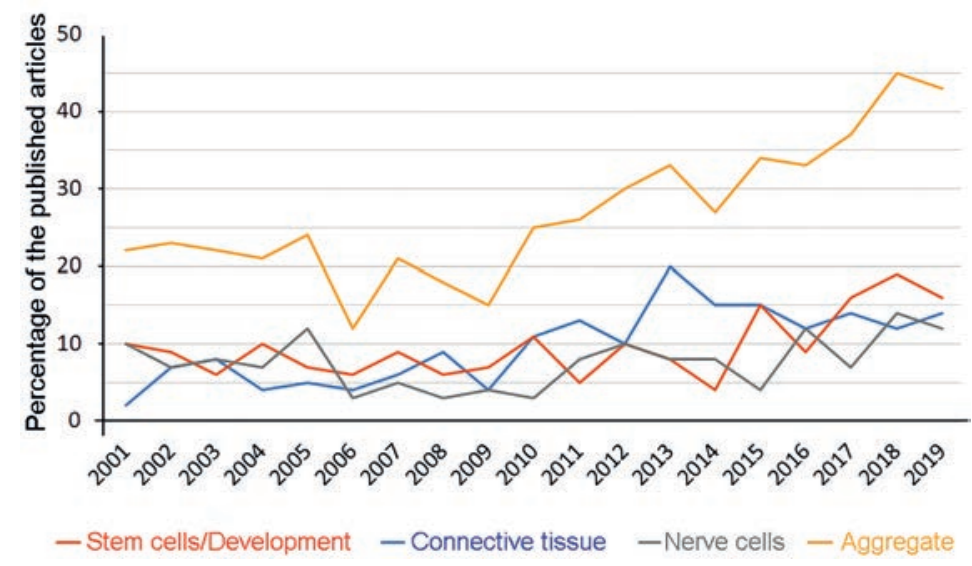

Figure 2. Percentage of the articles published in the European Journal of Histochemistry on stem cells and development, the connective tissue, and nerve cells in the period 2001-19. 
Paraphrasing this sentence, one may say that the above-mentioned guiding principles of a trustworthy histochemical journal surely remain steadfast when opening the journal to high quality contributions by valued scientific societies that may help further widening the horizon of the histochemical science.

\section{References}

1. Pellicciari C. Histochemistry as a versatile research toolkit in biological research, not only an applied discipline in pathology. Eur J Histochem 2018;62: 3006.

2. Malatesta M. Ultrastructural histochemistry in biomedical research: Alive and kicking. Eur J Histochem 2018;62: 2990.

3. Badria FA, Aboelmaaty WS. Plant histochemistry: A versatile and indispensable tool in localization of gene expression, enzymes, cytokines, secondary metabolites and detection of plants infection and pollution. Acta Sci Pharmaceut Sci 2019;3:88-100.

4. Wick MR. Diagnostic histochemistry: A historical perspective. Semin Diagn Pathol 2018;35:354-9.

5. Intartaglia M, Sabetta R, Gargiulo $M$, Roncador G, Zito Marino F, Franco R. Immunohistochemistry for cancer stem cells detection: Principles and methods. Methods Mol Biol 2018;1692:195-211.

6. Pellicciari C. Histochemistry in biology and medicine: a message from the citing journals. Eur J Histochem 2015;59: 2610.

7. Pellicciari C, Biggiogera M. Histochemistry of single molecule: Methods and protocols. Methods in Molecular Biology. vol. 1560. Humana Press, New York: 2017.

8. Peters AL, van Noorden CJF. Single cell cytochemistry illustrated by the demonstration of glucose-6-phosphate dehydrogenase deficiency in erythrocytes. Methods Mol Biol 2017;1560:313.

9. Pellicciari C. Histochemistry today: detection and location of single molecules. Eur J Histochem 2017;61:2885

10. Coleman R. The impact of histochemistry - a historical perspective. Acta Histochem 2000;102:5-14.

11. https://link.springer.com/journal/418

12. https://journals.sagepub.com/aimsscope/JHC

13. https://www.jstage.jst.go.jp/browse/ ahc/_pubinfo/-char/en

14. https://journals.viamedica.pl/folia_histochemica_cytobiologica/index

15. https://www.ejh.it

16. Barogozzi C, Bignardi C, Bozza G,
Ciaranfi E, Giordano A, Rossi F, et al. Atti del $1^{\circ}$ Congresso Nazionale della Società Italiana di Istochimica. Riv Istoch Norm Pat 1958;IV:1-48.

17. Carnevali O, Di Primio R. Proceedings of the 65th Congress of the GEI-Italian Society of Development and Cell Biology (GEI-SIBSC) - 38th Congress of the Italian Society of Histochemistry (SII). Eur J Histochem 2019;63(s2):137. doi: 10.4081/ejh.2019.3052.

18. Boiani M, Crosetto N, Redi C. Pavia symposium on embryos and stem cells. Eur J Histochem 2009;52:79-81.

19. Falcieri E, Cenacchi G. XXII Annual Meeting of the Italian Group for Ultrastructural Pathology SIAPEC GIPU. Eur J Histochem 2012;56(s1):112. doi: 10.4081/ejh.2012.s1.

20. Meschini S. Correlative microscopy in life and materials sciences. Eur $\mathrm{J}$ Histochem 2017;61(s4):1-8. doi: 10. 4081/ejh.2017.2864.

21. Meschini S, Caraglia SC. Therapeutic nanoproducts: from biology to innovative technology. Eur J Histochem 2019;63(s1):1-8.

22. Nardi I. Proceedings of the $61 \mathrm{st}$ Congress of the Italian Embryological Group (GEI) - 36th Congress of the Italian Society of Histochemistry. Eur J Histochem 2015;59(s1):1-37. doi: 10.4081/ejh.2015.2537.

23. Anastasi G, Puzzolo D. Proceedings of the 37 th Congress of the Italian Society of Histochemistry. Eur J Histochem 2017;61(s2);1-12. doi: 10.4081/ejh. 2017.2844 .

24. Verderame M, Limatola E, Scudiero R. Metallothionein expression and synthesis in the testis of the lizard Podarcis sicula under natural conditions and following estrogenic exposure. Eur J Histochem 2017;61:2777.

25. Aidos L, Pinheiro Valente LM, Sousa V, Lanfranchi M, Domeneghini C, Di Giancamillo A. Effects of different rearing temperatures on muscle development and stress response in the early larval stages of Acipenser baerii. Eur J Histochem 2017;61:2850.

26. Maeda Y, Miwa Y, Sato I. Expression of CGRP, vasculogenesis and osteogenesis associated mRNAs in the developing mouse mandible and tibia. Eur $\mathbf{J}$ Histochem 2017;61:2750.

27. Liu W, Wang C, Yu H, Liu S, Yang J. Expression of acetylated tubulin in the postnatal developing mouse cochlea. Eur J Histochem 2018 8;62:2942.

28. Casini A, Vaccaro R, Toni M, Cioni C. Distribution of choline acetyltransferase (ChAT) immunoreactivity in the brain of the teleost Cyprinus carpio. Eur J Histochem 2018;62:2932.
29. Kálmán M, Oszwald E, Adorján I. Appearance of $\beta$-dystroglycan precedes the formation of glio-vascular end-feet in developing rat brain. Eur J Histochem 2018;62:2908.

30. Longo M, Boiani M, Redi CA, Monti M. Cytoplasmic lattices are not linked to mouse 2-cell embryos developmental arrest. Eur J Histochem 2018;62:2972.

31. Mitsuoka K, Miwa Y, Kikutani T, Sato I. Localization of CGRP and VEGF mRNAs in the mouse superior cervical ganglion during pre- and postnatal development. Eur J Histochem 2018; 62:2976.

32. Martins MF, Martins P, Gonçalves CA. Presence of $\mathrm{N}$-acetylgalactosamine/ galactose residues on bronchioloalveolar cells during rat postnatal development. Eur J Histochem 2019;63:3040.

33. Faraj R, Irizarry-Alfonzo A, Puri P. Molecular characterization of nephron progenitors and their early epithelial derivative structures in the nephrogenic zone of the canine fetal kidney. Eur J Histochem 2019;63:3049.

34. Diomede F, Thangavelu SR, Merciaro I, D'Orazio M, Bramanti P, Mazzon E, et al. Porphyromonas gingivalis lipopolysaccharide stimulation in human periodontal ligament stem cells: role of epigenetic modifications to the inflammation. Eur J Histochem 2017; 61:2826.

35. Rabinovich I, Martins Sebastião AP, Silveira Lima R, Cícero de Andrade U, Schunemann E Jr, Furlan Anselmi K, et al. Cancer stem cell markers ALDH1 and CD44+/CD24- phenotype and their prognosis impact in invasive ductal carcinoma. Eur J Histochem 2018;62: 2943.

36. Dall'Oca C, Maluta T, Micheloni GM, Cengarle M, Morbioli G, Bernardi P, et al. The biocompatibility of bone cements: progress in methodological approach. Eur J Histochem 2017;61: 2673.

37. Boháč M, Danišovič L, Koller J, Dragúňová J, VargaI. What happens to an acellular dermal matrix after implantation in the human body? A histological and electron microscopic study. Eur J Histochem 2018;62:2873.

38. Pizzicannella J, Marconi GD, Pierdomenico SD, Cavalcanti MFXB, Diomede F, Trubiani O. Bovine pericardium membrane, gingival stem cells, and ascorbic acid: a novel team in regenerative medicine. Eur J Histochem 2019;63:3064.

39. Conti G, Bertossi D, Dai Prè E, Cavallini C, Scupoli MT, Ricciardi G, et al. Regenerative potential of the Bichat fat pad determined by the quantification 
of multilineage differentiating stress enduring cells. Eur J Histochem 2018; 62:2900.

40. Costanzo M, Boschi F, Carton F, Conti G, Covi V, Tabaracci G, et al. Low ozone concentrations promote adipogenesis in human adipose-derived adult stem cells. Eur J Histochem 2018;62: 2969.

41. Colitti M, Boschi F, Montanari T. Dynamic of lipid droplets and gene expression in response to $\beta$ aminoisobutyric acid treatment on 3T3L1 cells. Eur J Histochem 2018;62: 2984.

42. Kawai M, Kataoka Y, Sonobe J, Yamamoto H, Maruyama H, Yamamoto $\mathrm{T}$, et al. Analysis of mineral apposition rates during alveolar bone regeneration over three weeks following transfer of BMP-2/7 gene via in vivo electroporation. Eur J Histochem 2018;62:2947.

43. Hashimoto K, Oda Y, Nakamura F, Kakinoki R, Akagi M. Lectin-like, oxidized low-density lipoprotein receptor1-deficient mice show resistance to agerelated knee osteoarthritis. Eur J Histochem 2017;61:2762.

44. Yamagishi K, Tsukamoto I, Nakamura F, Hashimoto K, Ohtani K, Akagi M. Activation of the renin-angiotensin system in mice aggravates mechanical loading-induced knee osteoarthritis. Eur J Histochem 2018:62:2930.

45. Hashimoto K, Oda Y, Nakagawa K, Ikeda T, Ohtani K, Akagi M. LOX-1 deficient mice show resistance to zymosan-induced arthritis. Eur J Histochem 2018;62:2847.

46. Battistelli M, Favero M, Burini D,
Trisolino G, Dallari D, De Franceschi L, et al. Morphological and ultrastructural analysis of normal, injured and osteoarthritic human knee menisci. Eur J Histochem 2019:63:2998.

47. Manca R, Glomski CA, Pica A. Evolutionary intraembryonic origin of vertebrate hematopoietic stem cells in the elasmobranch spleen. Eur J Histochem 2018;62:2987.

48. Manca R, Glomski CA, Pica A. Hematopoietic stem cells debut in embryonic lymphomyeloid tissues of elasmobranchs. Eur J Histochem 2019: 63:3060.

49. Shi Z, Greene KW, Nicholls KP, Hu D, Tirnitz-Parker JEE, Yuan Q, et al. Immunofluorescent characterization of non-myelinating Schwann cells and their interactions with immune cells in mouse mesenteric lymph node. Eur J Histochem 2017;61:2827.

50. Ma B, Yin C, Hu D, Newman M, Nicholls PK, Wu Z, et al. Distribution of non-myelinating Schwann cells and their associations with leukocytes in mouse spleen revealed by immunofluorescence staining. Eur J Histochem 2018:62:2890.

51. Hu D, Nicholls PK, Claus M, Wu Y, Shi $\mathrm{Z}$, Greene WK, et al. Immuno-fluorescence characterization of innervation and nerve-immune cell interactions in mouse lymph nodes. Eur J Histochem 2019;63:3059.

52. Liu J, Cai L, He Y, Yang J. Apoptosis pattern and alterations of expression of apoptosis-related factors of supporting cells in Kölliker's organ in vivo in early stage after birth in rats. Eur J Histochem
2017;61:2706

53. Hou S, Chen J, Yang J. Autophagy prec.edes apoptosis during degeneration of the Kölliker's organ in the development of rat cochlea. Eur J Histochem 2019;63:3025.

54. Farina V, Lepore G, Biagi F, Carcupino M, Zedda M. Autophagic processes increase during senescence in cultured sheep neurons and astrocytes. Eur J Histochem 2018:62:2891.

55. Favorito R, Monaco A, Grimaldi MC, Ferrandino I. Effects of cadmium on the glial architecture in lizard brain. Eur J Histochem 2017;61:2734.

56. Monaco A, Capriello T, Grimaldi MC Schiano V, Ferrandino I. Neurodegeneration in zebrafish embryos and adults after cadmium exposure. Eur J Histochem 2017;61: 2833.

57. Mangas A, Heredia M, Riolobos A, De la Fuente A, Criado JM, Yajeya J, et al. Overexpression of kynurenic acid and 3-hydroxyanthranilic acid after rat traumatic brain injury. Eur J Histochem 2018:62:2985.

58. Paradiso B, Simonato M, Thiene G, Lavezzi A. From fix to fit into the autoptic human brains. Eur J Histochem 2018;62:2944.

59. Braak H, Feldengut S, Kassubek J, Yilmazer-Hanke D, Del Tredici K. Two histological methods for recognition and study of cortical microinfarcts in thick sections. Eur J Histochem 2018:62:2989.

60. Taatjes DJ, Schrader M, Koji T, Roth J Histochemistry and Cell Biology: 61 years and not tired at all. Histochem Cell Biol 2019;152:1-11. 